QUARTERLY TECHNICAL PROGRESS REPORT

DOE/MC/21337--Tl

DE92 017751
July 15,1985

Report No. 7904-03

Report Period: $4 / 01 / 85$ to $6 / 30 / 85$

\title{
Objective:
}

The objective of the proposed work is to demonstrate the operational and economic feasibility of using high-temperature ceramic filters for particulate control in a variety of coal gasification power generating systems.

Method of Approach

The proposed work will consist of three tasks. In task 1, the performance of a ceramic filter will be evaluated under actual gasifier conditions at the bench scale. Performance will be measured primarily in terms of collection efficiency, cleanability, and durability. Power consumption and general ease of operation will be assessed. Data generated in this task will also be used to assess design, operation, and performance of systems when scaled-up to commercial size. In task 2, alternative design principles will be tested to seek improved performance, lower cost, or wider applicability of the gasifier filter. In task 3, a commercial-scale gasifier filter design will be generated using data obtained from the first two tasks and information from the literature. This design will be used to estimate the installed and operating costs of the filtration system and provide an evaluation of the technical and economic feasibility of using ceramic filters for gasifier particulate cleanup.$$
\text { if }
$$ 


\section{IEESHNICAL PRQGERESE}

The technical progress of each of the tasks of this project during the months of April, May, and June is given in the following paragraphs.

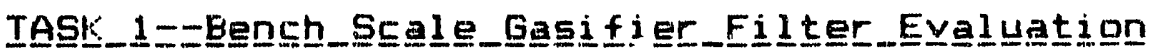

In April, bids packages were sent out for procuring the major pieces of equipment. Bids were received in mid-April, and vendors were selected. Other equipment, such as solenoid valves and pressure regulators were ordered through catalogs. A delivery and assembly schedule was put together (see Attachment A). The current status of each step on this schedule is indicated.

All equipment was received in May and early June. The pressure vessel arrived at the beginning of June after having refractory installed. There were several minor problems with the refractory in the vessel as received. The refractory was not cured when received. Acurex assembled a heating system to partially cure the refractory. The refractory will be completely cured when the internal heater is installed. Also the ring which seals the filter cage to the upper flange was not fabricated correctly. This was subsequently corrected. Refractory was present on the $f l$ ange sealing surfaces and had to be removed. Also one of the nozzles was plugged with refractory and had to be drilled out. Also, refractory molds were left in place after the vessel was delivered to Acurex, and had to be routed out. 
Installation of the internal heater was attempted in midJune. The heater was found to be 1 arger in diameter than specified. The heater was sent back to the manufacturer for correction with projected arrival at Acurex after correction in mid-July. The pulse solenoid valve was tested for proper operation before scheduled installation. It was found to operate improperly and was sent back to the manufacturer for repair. Scheduled arrival at Acurex after epair is mid-July.

The control cabinet was assenbled in May and early June. Check-out of the cabinet wiring and controls took place in midJune. The cabinet worked as planned and was readied for shipping.

In mid-May, the preliminary detailed test plan (see Attachment (B) for the scheduled testing at Morgantown was sent to DOE for review. Review comments have not been received.

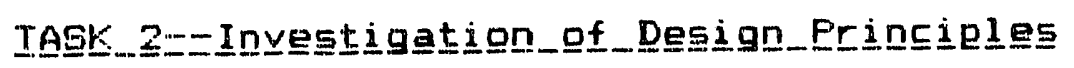

Task 2 testing consists of two phases. In one phase, the ceramic materials which are to be use as filters for the gasifier stream are exposed to a simulated gasifier environment. They are then mechanically tested to measure their integrity. In the other phase, the ceramic materials are used as actual hot gas filters in a bench scale rig. In the following, the various tasks performed since April are described. First the construction and shake down of the various test equipment will be covered. Then the test results will be described. 


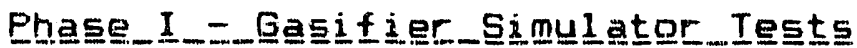

The gasifiew simulation rig was used to expose fabric strips to a simulated gasifier environment at 1600 OF. The mechanical properties of these strips were then compared to the mechanical properties of fabrics heated in air in order to compare the effect of the gasifier environment relative to an hot oxidizing stream. Figure 1 shows the overall test plan for the gasifier simulation tests. A sketch of the gasifier simulation rig is shown in figure 2 and figure 3 is a photograph of the rig. The simulation test cell is a RA 330 stainiess steel can into which the ceramic strips for testing were placed. The test cell was then put into an oven. After being heated to 1600 OF, the fabric strips were exposed to a simulated gasifier gas mixture approximately of the following composition:

$$
\begin{aligned}
& \mathrm{CO}-13.5 \% \\
& \mathrm{CO}_{2}-10 \% \\
& \mathrm{H}_{2}-17 \% \\
& \mathrm{H}_{2} \mathrm{O}-17 \% \\
& \mathrm{CH}_{4}-3.5 \% \\
& \mathrm{~N}_{2}-38 \% \\
& \mathrm{H}_{2} \mathrm{~S}-0.3 \% \\
& \mathrm{NaCl} \operatorname{trace}
\end{aligned}
$$

\section{DISCLAIMER}

\footnotetext{
This report was prepared as an account of work sponsored by an agency of the United States Government. Neither the United States Government nor any agency therenf, nor any of their employees, makes any warranty, express or implied, or assumes any legal liability or responsibility for the accuracy, completeness, or usefulness of any information, apparatus, product, or process disclosed, or represents that its use would not infringe privately owned rights. Reference herein to any specific commercial product, process, or service by trade name, trademark, manufacturer, or otherwise does not necessarily constitute or imply its endorsement, recommendation, or favoring by the United States Government or any agency thereof. The views and opinions of authors expressed herein do not necessarily state or reflect those of the United States Government or any agency thereof.
} 
Figure 1 Test Matrix for Gasifier Filter Fabric Durability Evaluation



GENERAL CHARACTERIZATION

. WE I GHT

- THICKNESS

- THREAD COLNT

- YARN AND FIBER STRUCTURE.

MECHANICAL TESTS

- ROOM TEMPERATURE FLEX

. CRUSH

- TENSILE

SEM/EDX

$a_{2}$ filter fabrics have been selected:

fabric $F$ and

fabric $S$ 


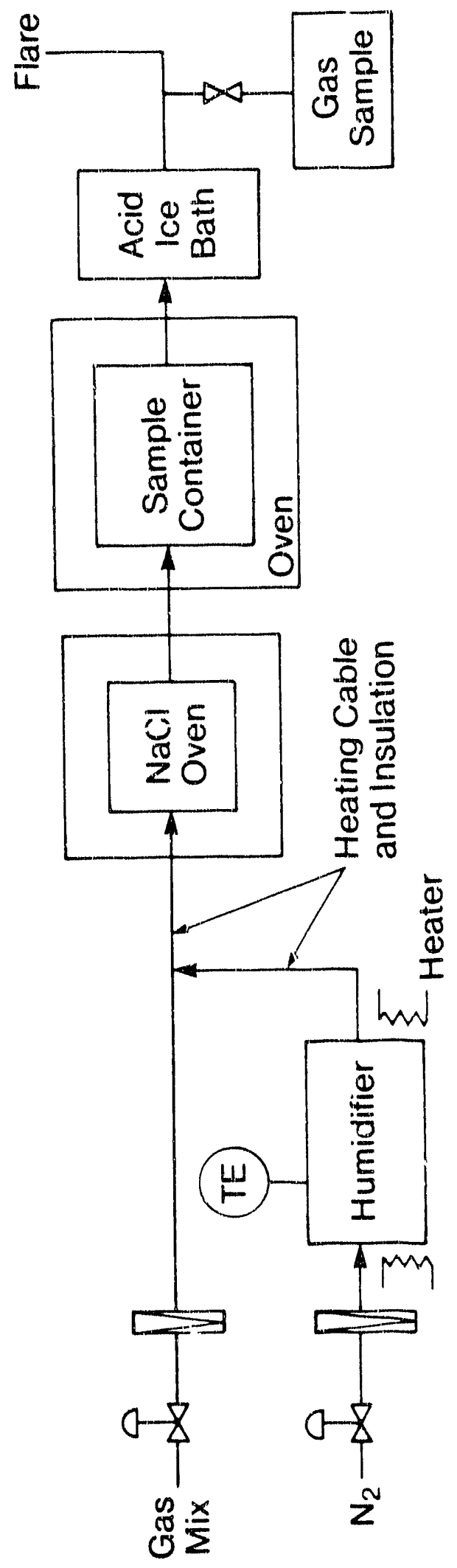

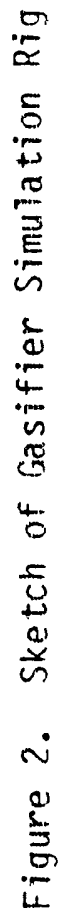




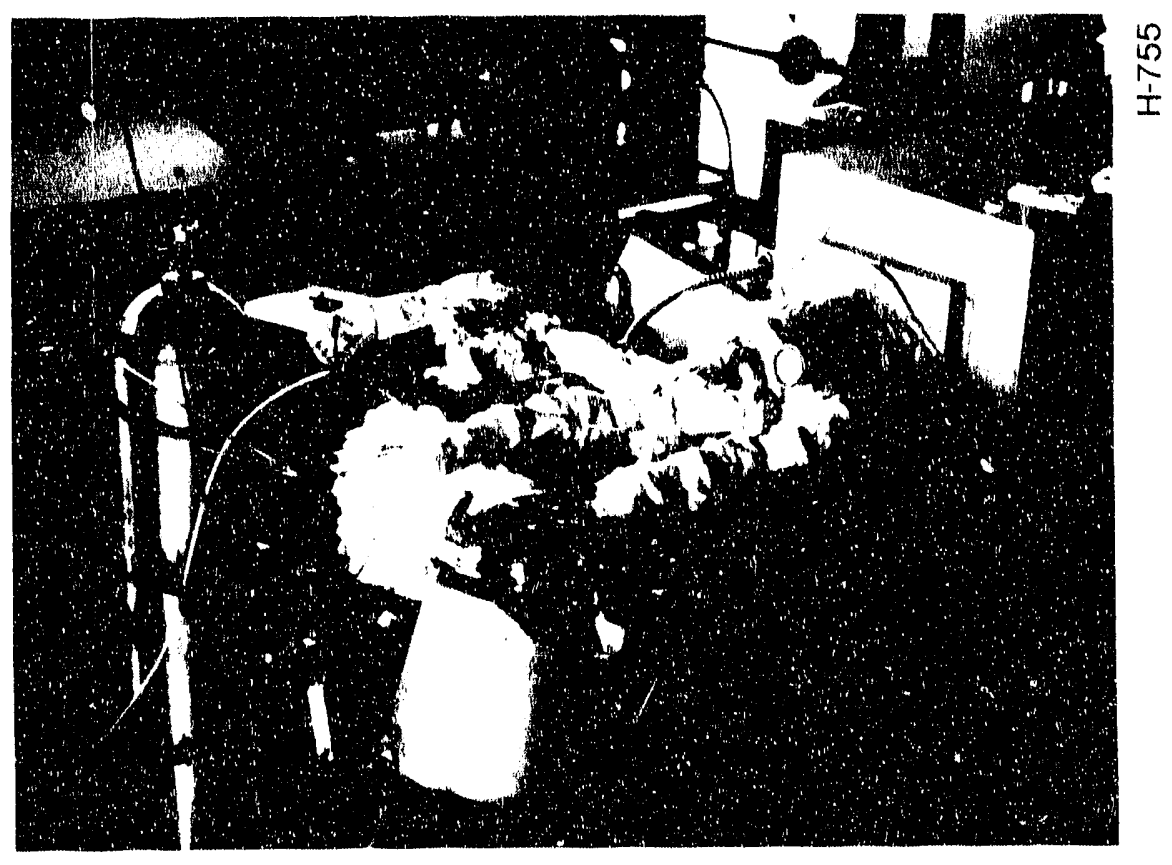

Figure 3. Photograph of Gasified Simulation Rig

13 
The simulated gasifier gas mixture was produced by mixing humidified nitrogen with a gas mixture containing $\mathrm{CO}_{2}, \mathrm{CO}, \mathrm{CH}_{4}$, $\mathrm{H}_{2}$, and $\mathrm{H}_{2}$ S. Trace amounts of alkali are next added to the gas by passing it through a heated tube containing NaCl crystals. Doing shakedown, the original $1 / 8$ " tubing for the test cell feed and exit lines were replaced with $1 / 4$ "tubing and the residence time was increased from $2 \mathrm{~min}$ to $8 \mathrm{~min}$. This was to prevent plugging which occurred during the early tests.

Tests were performed to verify that the fabric was being exposed to alkali vapor. The impinger solution which collected water vapor in the exit gas from the test cell was analyzed for sodium using atomic adsorption techniques. Sodium was found equivalent to about $4 \%$ of the theoretical amount of sodium that was vaporized in the alkali addition oven. A test was also run with the heated gas mixture bypassing the test cell and going directly to the impinger. Sodium was found in the impinger equivalent to about $25 \%$ of what would be expected if the gas stream was completely saturated with Nacl vapor. The gas stream was exposed to NaCl crystals at about 1300 OF which gives a theoretical value of $36 \mathrm{ppm} \mathrm{NaCl}$ by volume in the gas. The above test implied that the actual sodium concentration in the simulation gas may have been 9 ppm.

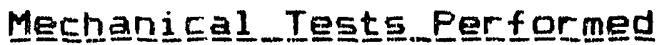

The mechanical properties measured after the treatments described in figure 1 were flex resistance, crush resistance, and 
tensile strength. All mechanical tests were performed at room temperature.

Two fabrics 1 abeled $F$ and $S$ were tested. Fabric $F$ is the primary candidate for the gasifier filter and has a texturized surface. It is woven from yarns formed from a combination of staple fibers twisted with continuous filaments. Fabric 5 is made of the same material as the backup candidate for the gasifier filter except it is in a five-harness weave. Although the five-harness weave is not the same weave used for the actual backup filter, it was considered acceptable as a representative fabric for examining the effect of the gasifier gaseous environment on the material.

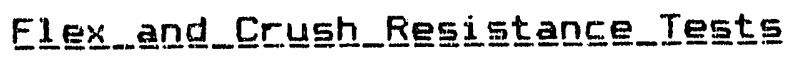

The crush and flex resistance test apparatus were built under the just completed DOE/METC project to test caranic materials. The crush test apparatus from the previous project was used without modification. In this test, a 6.1 pound weight with a cylindrical surface was impacted on a $2 "$ wide strip until failure. The point of failure was determined by a 1.4 pound tensioning weight hanging from one end which pulled the fabric apart.

In the flex test, a $2^{\prime \prime}$ wide strip of fabric was hung across a freely rotating metal rod and 2.1 pounds were hung from the specimen. The sample was then pulled back and forth across the rod until the material broke. The fabric strip was flexed over a 
metal rod supported over cartridge bearings which enables the rod to rotate freely. In the previous project the flex test was performed at $1600{ }^{\circ} \mathrm{F}$ with a rotating ceramic sleeve.

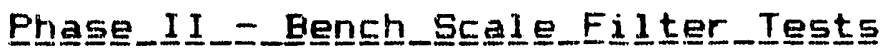

The bench scale filter test facility was also used on the previous project, however for tests in this project the cage was modified allowing different caye designs to be tested with a minimum of dangerous complications. Also the perforated metal cage used for the previous testing was slightly too large for one of the filter tubes that is being tested, so the cage was made smaller in diameter.

\section{Stㅡ르늩}

The gasifier simulation tests have been finished except for the tensile strength measurements on the fabric strips. Also, the first test in the bench scale filter test rig testing was completed in the first part of July. The results from the tests completed through the end of June are described in the following sections.

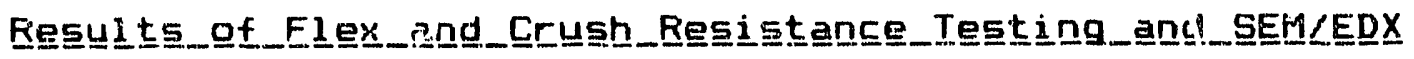

The mechanical properties of the ceramic filter fabrics were 
evaluated after exposure to different temperature and gas environments. The purpose of these tests were to examine the effect of the gasifier environment on ceramic fabric durability. The different exposure conditions are shown in figure -

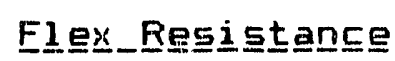

Table 1 shows the values measured for the flex resistance. Fabric $S$ showed a flex resistance much higher than that of fabric $F$, even through $F$ contains a significant amount of the same fibers that were used to weave fabric 5 . In the just completed DOE/METC Ceramic Material Testing Program (contract DE-AC2183MC20110), fabric WN (which is the same as 5 but from a different loatch) and fabric WF (which was similar to fabric F except it was woven with an Inconel wire mat:rix and contained no 5 fibers) were tested at $16000^{\circ}$ in the heat flex test. WN had a higher heat flex resistance than WF (2225 flexes versus 329 flexes). This difference in flex resistance did not seem to effect their short term durability as a filter as both performed well during 24 hours of PFBC dust collection at $16500^{\circ}$. 


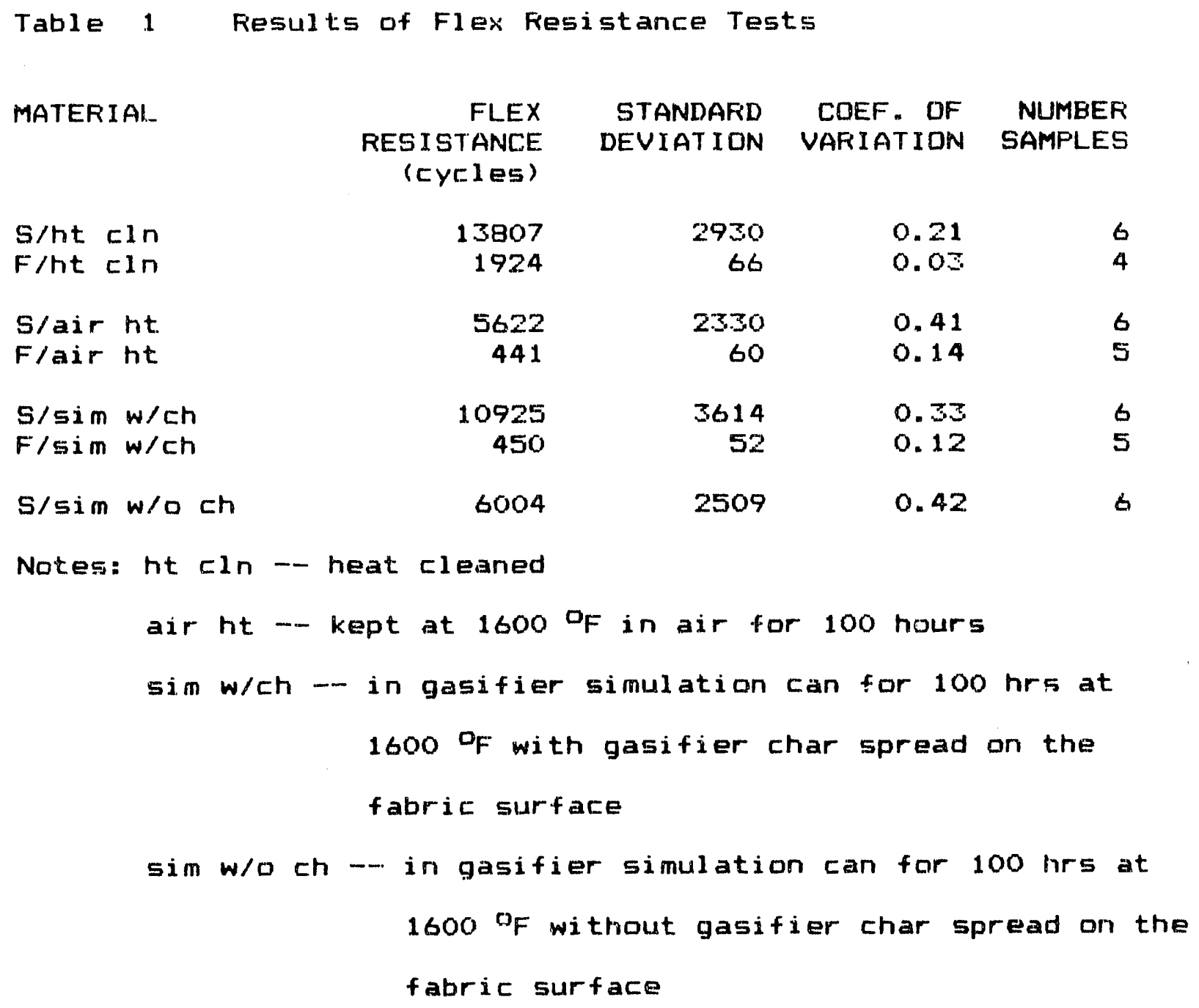


The coefficient of variation was different between fabrics $F$ and 5 . Tinere was more scatter in the data when testing 5 than when testing $F$. Since 5 lasts longer in the flex test, there is more time for differences due to nonuniform weaving and handling to become apparent.

Between materials heated in the simulated gasifier environment and in air, no nes :ive difference in flex resistance was noticed. For material 5 , the sample that was exposed to the gasifier environment with char showed better flex resistance than the material heated in air. These results imply that the mechanical integrity of the filters used in a gasifier environment should be no worse than that of the filters which are used in an hot oxidizing environments.

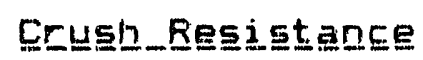

Table 2 shows the results of the crush resistance test. The differences between the results of these tests was less pronounced than those of the flex resistance test. Again, material exposed to the simulated gasifier environment did not show any negative effects when compared to the material that was heat treated in air. 
Table 2 Results of Crush Resistance Tests

\begin{tabular}{|c|c|c|c|c|}
\hline MATERIAL & $\begin{array}{r}\text { CRUSH } \\
\text { RESISTANCE } \\
\text { (rycles) }\end{array}$ & $\begin{array}{r}\text { OTANDARD } \\
\text { DEVIATION }\end{array}$ & $\begin{array}{l}\text { COEF. DF } \\
\text { VARIATIQN }\end{array}$ & $\begin{array}{l}\text { NUMBER } \\
\text { SAMPLES }\end{array}$ \\
\hline $\begin{array}{l}\text { S/hit clean } \\
\text { F/ht clean }\end{array}$ & $\begin{array}{l}1079 \\
1: 567\end{array}$ & $\begin{array}{l}610 \\
264\end{array}$ & $\begin{array}{l}0.56 \\
0.19\end{array}$ & $\frac{6}{5}$ \\
\hline $\begin{array}{l}\text { Slair ht } \\
\text { Flair ht }\end{array}$ & $\begin{array}{l}565 \\
435\end{array}$ & $\begin{array}{l}302 \\
131\end{array}$ & $\begin{array}{l}0.54 \\
0.30\end{array}$ & $\begin{array}{l}6 \\
5\end{array}$ \\
\hline $\begin{array}{l}\text { S/sim w/ch } \\
\text { F/sim w/ch }\end{array}$ & $\begin{array}{l}569 \\
435\end{array}$ & $\begin{array}{l}142 \\
124\end{array}$ & $\begin{array}{l}0.25 \\
0.29\end{array}$ & $\begin{array}{l}6 \\
85\end{array}$ \\
\hline S/sim w/o ch & 1520 & 1527 & 1.00 & 6 \\
\hline
\end{tabular}

\section{SEM/EDX Results}

SEM (scanning electron microscopy) and EDX (energy dispersive $x-r a y s)$ were also performed on the above fabrics after they had be sn subjected to the various temperature treatments.

Fo.- fabric S, EDX on the material exposed ta a gasifier envirorment with and without char, did not show any difference except for some iron and manganese on the sample with char. These peaks were most likely from the char. The silicon peak for the material with char was also a little larger than the one for the material without char. Sulfur and sodium were specifically looked for but none were found. The sensitivity of EDX is only in the 0.5 to $1 \%$ by weight range. SEM micrographs of the surface showed no interaction between the char and the ceramit surface. Figure 4 shows the SEM micrograph of fabric 5 with char. 
For fabric F that was exposed to the simulated gasifier environment with char, SEM showed that char was on the surface in higger clumps and also more into the center of the fabric as compared to fabric 5 . Figure 6 is a SEM micrograph of fabric $F$ with char. Because fabric F has a textured surface as compared to the smooth surface of fabric $S$, this was what would be expected. EDX showed some titanium and calcium peaks in addition to iron and manganese. Since there was more char on the $F$ sample, there was more for the EDX spectrometer to sense. Again sulfur and sodium were specifically looked for and none were found.

Samples of fabric 5 and fabric $F$ with Inconel wire were also exposed to an gasifier environment by KRW. Figures 5 and 7 are SEM micrograph of fabrics $F$ and $S$ exposed by KRW. For $S$, again no char surface interaction was noted. ECX showed a sulfur peak which we did not find on the sample from our gasifier simulator. The silicon peak on fabric 5 was also 1 arger when compared to the sample of $S$ that was exposed in our gasifier simulation rig without char. As discussed above, the sample of fabric $S$ exposed in our gasifier simulation rig with char also showed more silicon.

For fabric $F$ with Inconel wire exposed in the KRW gasifier, additional nickel and chromium peaks were found by EDX. This was probably from the wire. SEM of one of the actual fibers showed the surface to be evenly coated with a layer of char as compared to having lumps of char as found for fabric 5.

Figures 4, 5, 6, and 7 also show an comparison of the 
samples exposed in our gasifier simulator to the samples exposed by KRW. The KRW samples showed more char on the surface than the ones that were exposed in the gasifier simulation rig. Another sample of fabric 5 that was exposed in the gasifier simulation rig without char was also looked at. This was one of the original tests where the salt was located inside the test can exposing the fabric to very high Nacl concentrations. The part of the material with the high salt coating was very brittle. With SEM (see figure B), it appeared that the surface was either evenly coated with salt or very pitted. There also appeared to be material bridging between the fabrics strands. 


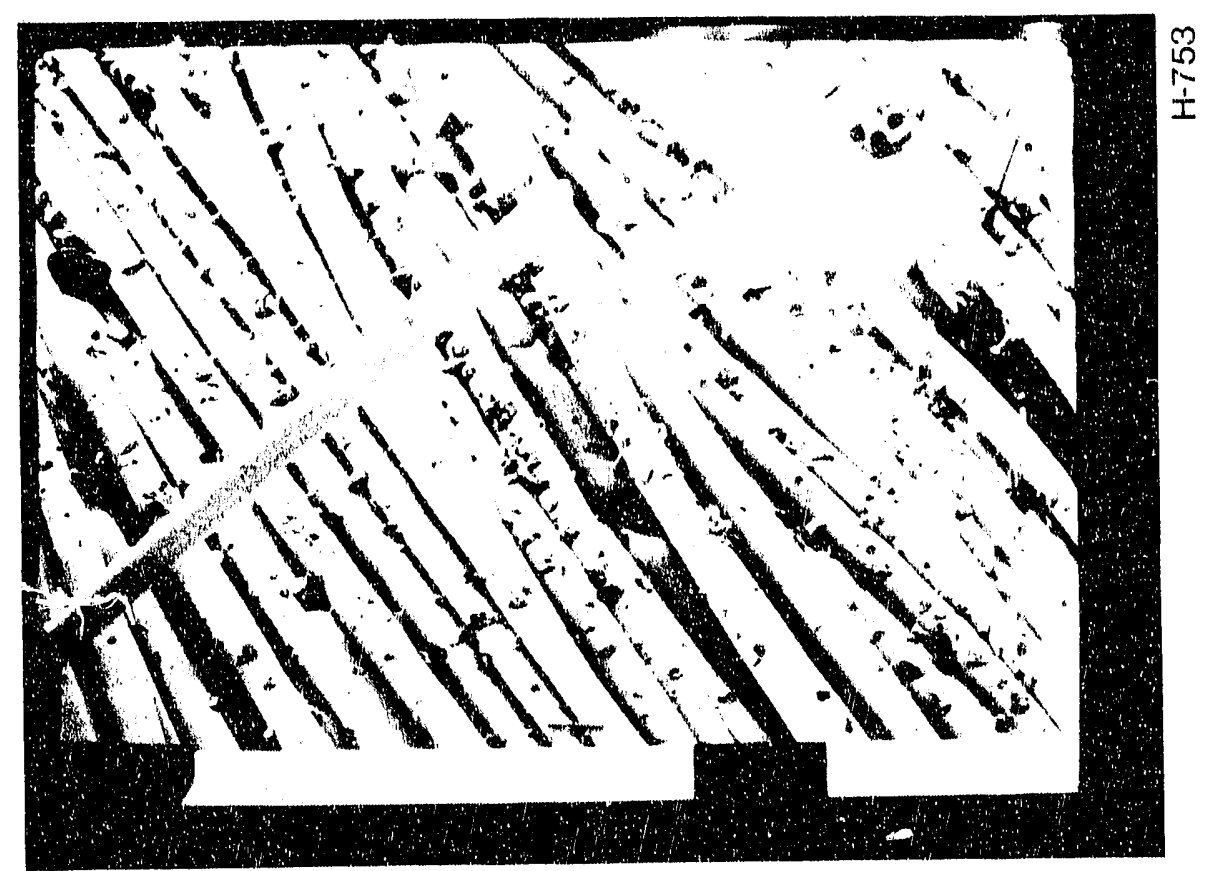

Figure 4. SEM Micrograph of Fabric S Exposed to Simulated Gasifier Environment with Char at 500X

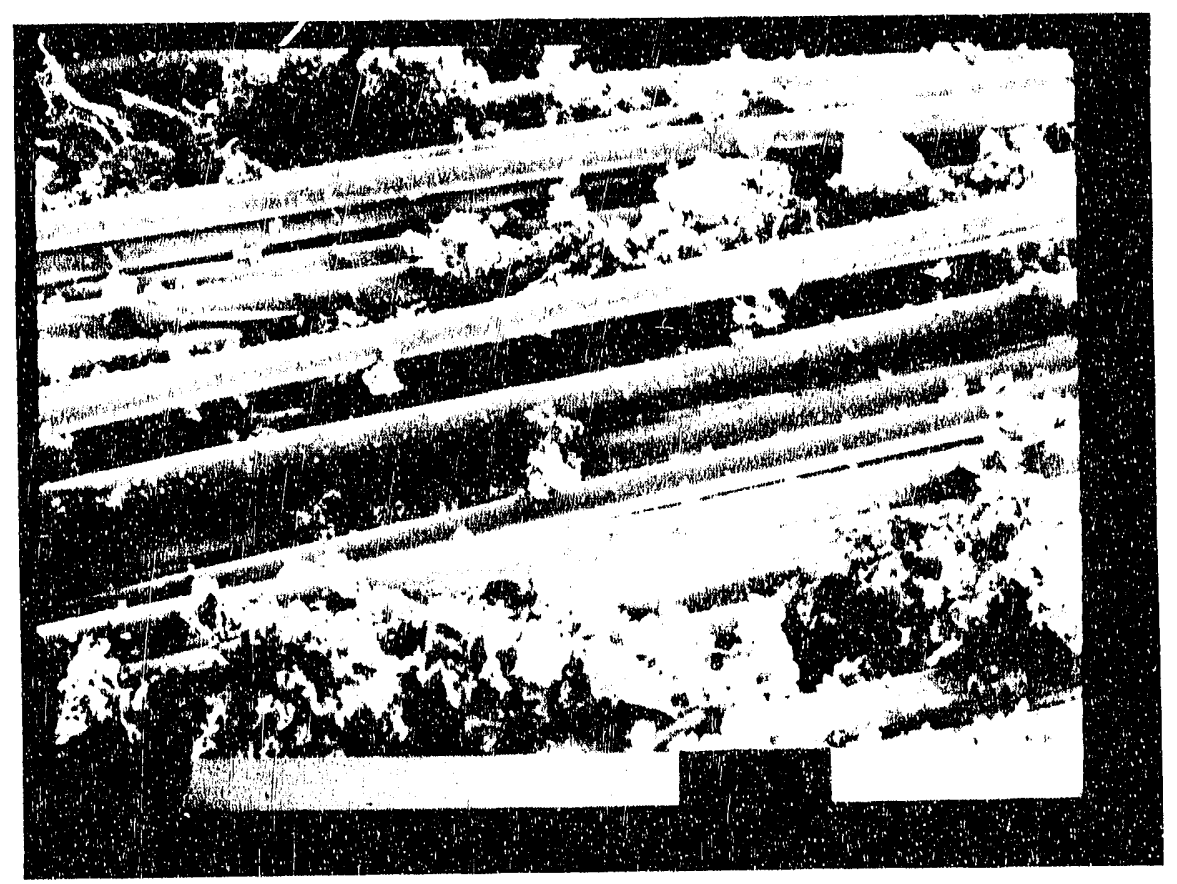

Figure 5. SEM Micrograph of Fabric S Exposed by KRW at 500X 


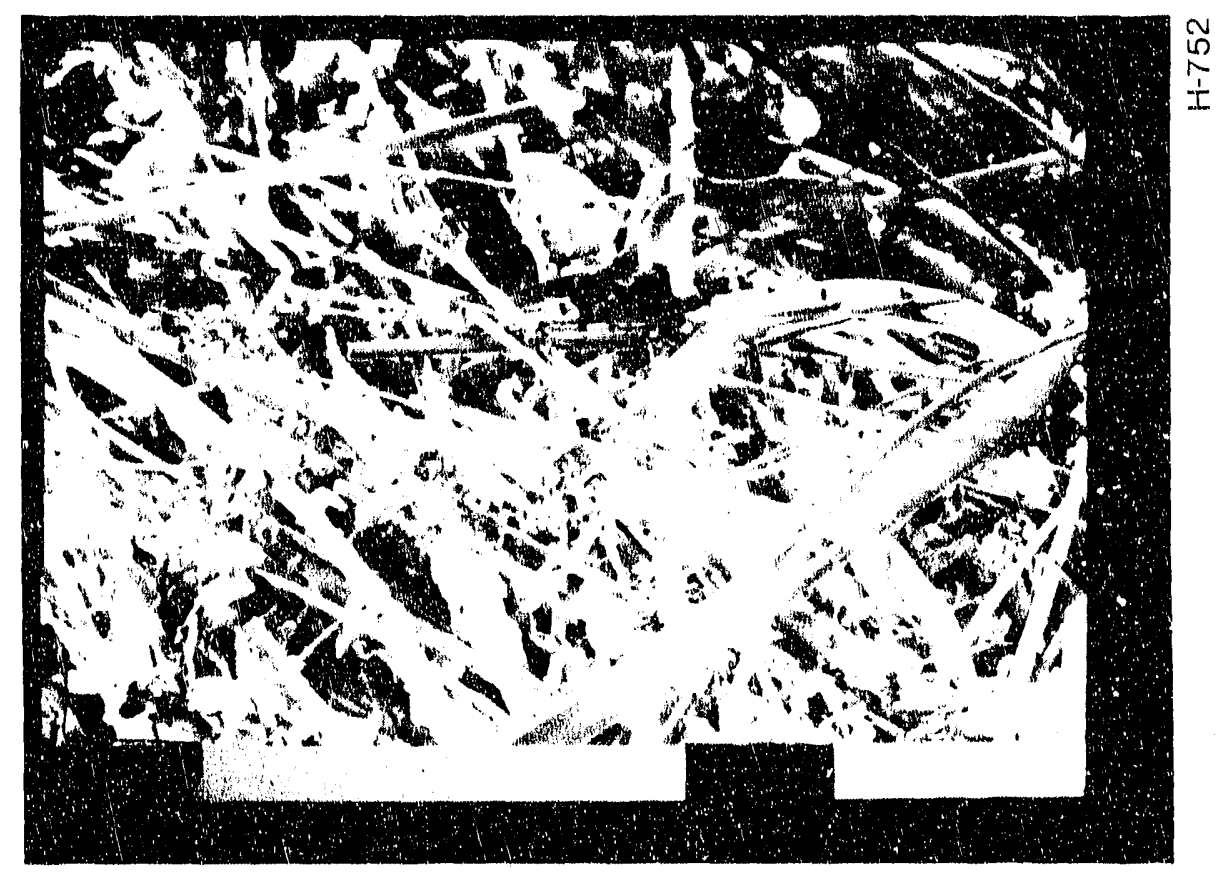

Figure 6. SEM Micrograph of Fabric F exposed to Simulated Gasifier Environment with Char at $500 x$

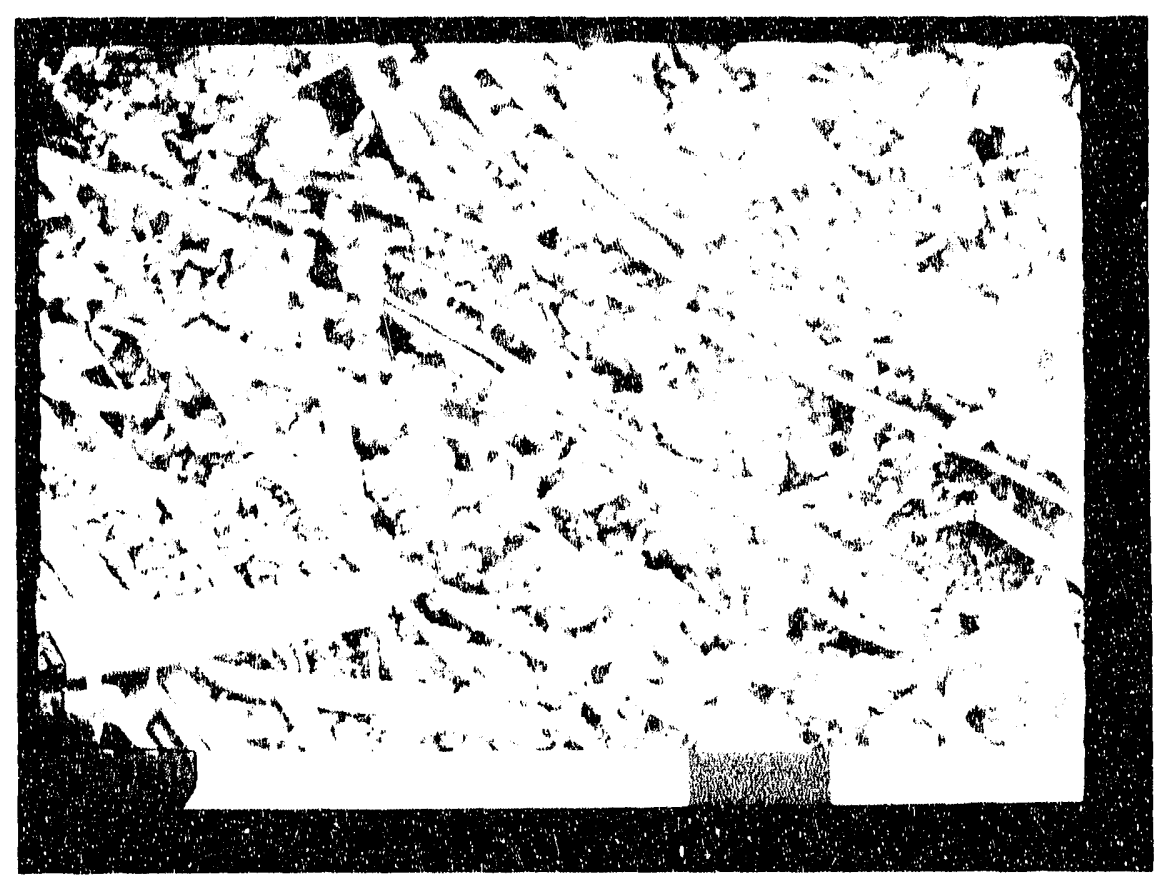

Figure 7. SEM Micrograph of Fabric F Exposed By KRW at 500x 


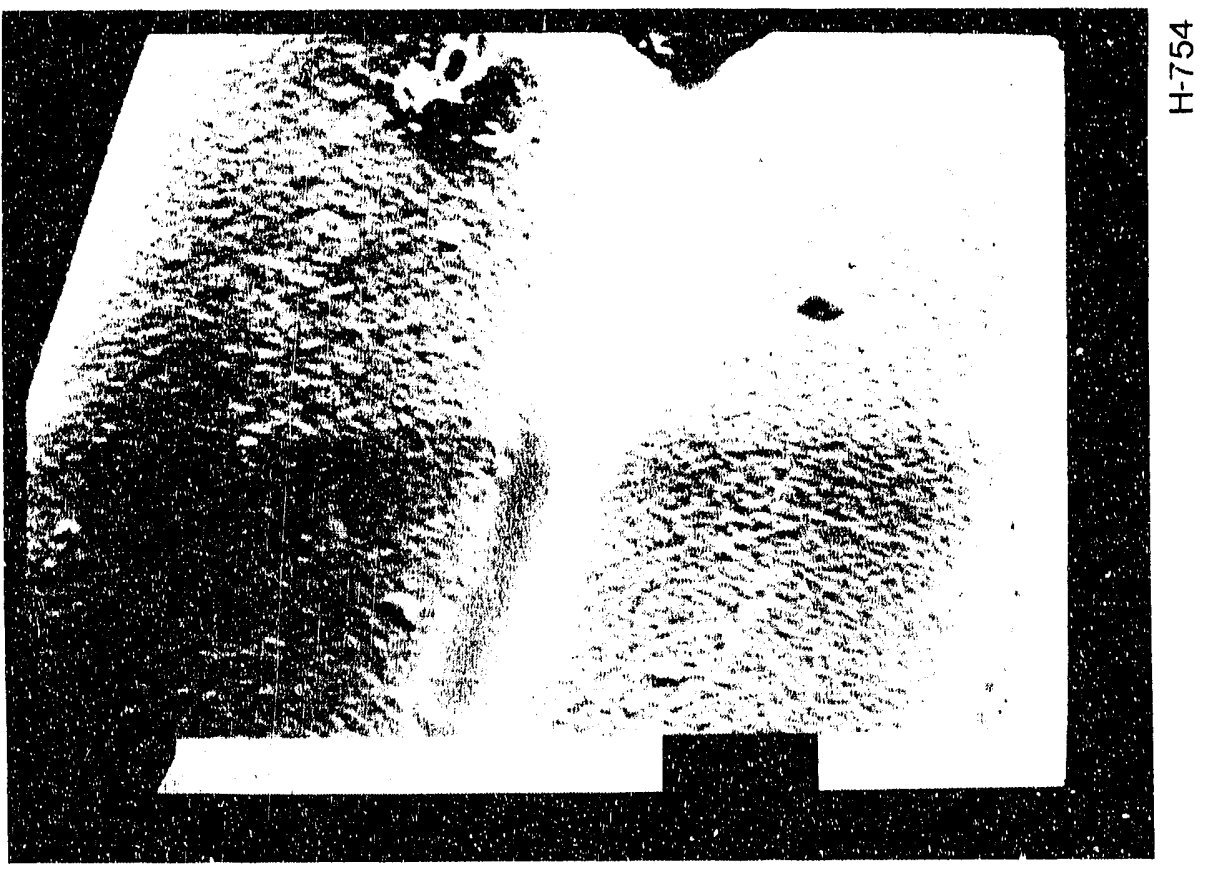

Figure 8. SEM Micrograph of Fabric S Overexposed to $\mathrm{NaCl}$ in Gasifier Simulator at 5000X 


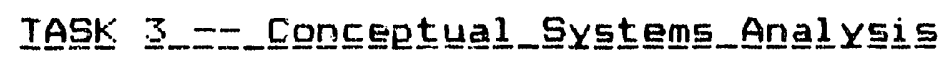

During the visit of the DOE Project Officer to Acurex on June 20th, we discussed the procedures to be used to commercially evaluate each of the hot gas cleanup devices. It was tentatively agreed to use the EPRI Technical Assessment Guide (TAG) as the basis for the commercial assessment. It was also agreed that a copy of TAG would be forwarded to Acurex. We have received the copy and are in the process of reviewing it.

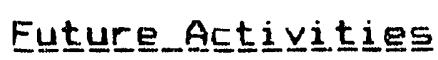

Dn Task 1, during the nest three months, the test facility will be shipped to Morgantown for testing on the DOE gasifier. There should be tentative results of the testing in October. These results should have been presented to DOE by the next quarterly report. On task 2, all testing will be completed and should have been documented by Dctober. Task 3 will be underway during the next quarter. 
Attachment $A$ 


\section{Tabl 1 Schedule for Freshipping Assembly and Fabrication}

Tasㅌ․

Issue bid package

Eidder response received

Let contracts

Pressure vessel fabrication

Site inspection

Fefractory installation

Site inspection

Pressure vessel transport to Acurex

Fressure vessel assembly

Electrical and instrum. assy.

checkout

Shipping equipment to METC

Hoftman box support fabrication

Pressure vessel support fab

\section{트모ㄴㅡㅗ}

Done

Done

Done

Done

Done

Done

Dane

Done

To be completed by July 26

Dane

To be completed by Aug 12

To be completed by Aug 21

Done

Done 
ATTACHMENT B

TEST PLAN AND PROCEDURES

FOR

GASIFIER FILTER EVALUATION

\author{
PROJECT 7904 -- TASK 1 \\ $D E-A C 21-84 M C 21337$
}

ACUREX CORPORATION

MAY 29, 1985 


\section{TEST PLAN}

This document presents the test and operating plan for the ceramic bag filter testing at DOE-METC and is divided into into seven sections:

.Filter mounting procedure

. Heat cleaning procedure

.Startup procedure

-Operating procedure

. Shutdown procedure

. Test conditions

-Test schedule

\section{FILTER MOUNT $\perp$ NG PROCEDURE}

1. The filter should be pulled over the cage in such a manner as to avoid srags or pul 1 s of the filter fabric. It is clamped just above the cage indentation(drawing 7904-G-302). After mounting, the filter should have sufficient length to extend three inches beyond the bottom of the cage.

Clamping procedure: $1 / 8$ inch thick Fiberfrax paper is cut into strips approximately 3 times as wide as the band clamp, and long enough to wrap around the filter. The Fiberfrax paper is wrapped around the filter at the clamping surface of the cage. The clamp is placed around the "bed" of Fiberfrax and tightened slowly until it is securely fastened to the cage. While tightening the clamp, take care to prevent the fabric under the clamp from bunching or folding, forming possible pathways for particulate to pass from the dirty side to the clean side.

3. The floating bottom piece is then inserted in to the end of the filter bag. There should be a $3 / 4$ inch gap between the bottom of the cage and the stop located on the floating bottom (drawing $7904-G-302$ )

4. Carefully turn the cage-filter assembly upright and mount to the top of the vessel (drawing 7904-G-308)

Mounting procedure: Place square Fiberfrax braid in the $510 t$ in the refractory lining of the vessel top (see drawing 7904-G-300). put two layers of $1 / 8$ inch Fiberfrax paper outside the circle formed by the braid. Push the flange of the filter cage over the bolts protruding from the refractory surface. Tighten the flange to the surface with RA330 nuts and washers. Before mounting the nuts and washers, coat the threads of the studs with high temperature lubricant such as Nevr-Seez or Fel-pro. When the filter flange is tightened to the mounting surface, it should crush the Fiberfrax paper and the square braid, forming a tight seal. There should not be any gaps or breaks visible between the flange and the mounting surface. If the braid does not project enough from the mounting surface, remove it and 1 ine the bottom 
of the trench with several layers of Fiberfrax paper then reinsert the braid and remount the filter assembly.

5. Using the eye hooks provided on the top of the vessel, carefuliy lower the assembly into the main vessel. Be very careful to avoid hitting or rubbing the Eilter against anything. Use a new Flexitallic gasket when mounting the vessel top.

6. Insert the studs through the flange holes and torque to the prescribed level according to the following procedure.

Torquing procedure: To be supplied later.

\section{HEAT CLEANING PROCEDURE}

1. Start low flow of air through the vessel.

2. Turn on the internal heater and begin to heat the filter.

3. Temperature-time profile of the heat cleaning sequence shall be as follows.

Heat filter to $100{ }^{\circ} \mathrm{C}\left(212 \mathrm{O}_{\mathrm{F}}\right)$ \& hold for crie hour
Heat filter to $200 \mathrm{O}^{\circ} \mathrm{C}\left(392 \mathrm{O}_{\mathrm{F}}\right)$ \& hold for one hour
Heat filter to $300{ }^{\circ} \mathrm{C}\left(572 \mathrm{O}_{\mathrm{F}}\right)$ \& hold for one hour
Heat filter to $400 \mathrm{O}^{\circ} \mathrm{C}\left(752 \mathrm{O}_{\mathrm{F}}\right)$ \& hold for one hour
Heat filter to $500{ }^{\circ} \mathrm{C}\left(1004 \mathrm{O}_{\mathrm{F})}\right.$ \& hold for twenty hours

\section{STARTUP PROCEDURE}

1. Power up control pariel and three-pen recorder.

2. Begin Nitrogen flow through the vessel.

3. After 5 minutes, begin heating vessel using internal heater.

4. Initially set heater control at $400^{\circ} \mathrm{F}$. Turn heater control up in $300^{\circ} \mathrm{F}$ increments whenever heater temperature reaches new setpoint.

5. Hold heater temperature at $1600^{\circ} \mathrm{F}$ for half hour before beginning flow of gasifier stream into the vessel. 


\section{OPERATING PROCEDIIRE}

1. Set pulse reservoir according to the following table.

$\begin{array}{ll}\text { Operating } & \text { Pulse } \\ \text { Pressure } & \text { Pressure } \\ 100 & 300 \\ 300 & 750\end{array}$

2. Set pulse duration initially to $60 \mathrm{msec}$.

3. Set operation mode to delta $p$ initiated cleaning.

4. Observe pulse reservoir pressure recovery after pulse cleaning. The pressure should not overshoot or undershoot the setpoint. Also the pressure should not float. Set the flow limiting valve on the pulse reservoir inlet line to the position that allows the pulse reservoir pressure to return to setpoint in one minute.

5. Cherk operation of the pulse solenoid valve.

6. Check operation of the on-line and off-line system.

7. Make sure controls are in automatic.

8. Check operation of three pen recorder.

9. Check pulse nitrogen supply hourly.

10. Follow contingency plan shown in table l incase of operational problems.

11. Measure filter performance as outlined in table 2 .

\section{SHUTDOWN PROCEDURE}

1. Shutoff flow of fuel gas thiough the filter.

2. Flow nitrogen through the vessel for 10 minutes.

3. Turn off internal heater.

4. Close valve between pulse solenoid valve and vessel.

5. Drain pressure from pulse reservoir.

6. Shutoff power to control panel. 


\section{TEST CONDITIONS}



The test conditions for the gasifier filter testing are given in Table 3 . 
Table 1. Contingency Plan in Case of Operational Problems

1. $\Delta P$ does not return to baseline after cleaning or $\Delta P$ baseline increasing with time

- Check to see if solenoid pulse valve is operating properly

- Increase reservoir pressure by increments of 50 psig

- Increase pulse duration to $100 \mathrm{msec}$

- Try offline cleaning

- Decrease face velocity

- If filter fails to clean effectively after all the above maneuvers, stop test to inspect pulse system and filter. Check to see if pulse is properly delivered. Check to see if dust is sticky or sintering on filter surface.

2. Poor collection efficiency

- If collection efficiency $<95$ percent after 5 hours and does not. improve, stop test and inspect filter

- If $\Delta P$ across filter drops suddeniy (without cleaning) or $\Delta P$ fails to increase with time, make sure gasifier conditions have not changed and measure collection efficiency

3. Short cleaning intervals

- If cleaning interval is $<3$ min and if baseline $\Delta P$ is increasing follow procedure 1

- If cleaning interval is $<3$ min but baseline $\Delta P$ seems fairly steady, increase $\Delta P$ set point for cleaning by 5 in. water interval. If cleaning interval does not improve, try offline cleaning or lower face velocity. 
Table 2. Measurements During Filter Operation

\begin{tabular}{|c|c|c|}
\hline Parameter & Purpose & $\begin{array}{l}\text { Frequency of } \\
\text { Measurement }\end{array}$ \\
\hline $\begin{array}{l}\text { Isokinetic dust loading } \\
\text { upstream and downstream } \\
\text { of filter }\end{array}$ & Collection efficiency & $\begin{array}{l}\text { Once at beginning } \\
\text { and once at end of } \\
\text { each test run. } \\
\text { Once every } \\
8 \text { hours. }\end{array}$ \\
\hline Baseline $\Delta P$ vs time & Cleanability & Continuous \\
\hline Cleaning cycle duration & Cleanability & Continuous \\
\hline $\begin{array}{l}\text { Filter inlet pressure, } \\
\text { temperature, flowrate }\end{array}$ & $\begin{array}{l}\text { Determine face velocity; } \\
\text { characterize test conditions }\end{array}$ & On disk \\
\hline $\begin{array}{l}\text { Filter downs tream } \\
\text { tempera ture }\end{array}$ & Heat loss estimate & On disk \\
\hline $\begin{array}{l}\text { Visual inspection of } \\
\text { post-test bag condition }\end{array}$ & $\begin{array}{l}\text { Short-term durability; } \\
\text { projected durability }\end{array}$ & End of all tests \\
\hline $\begin{array}{l}\text { Fabric tensile strength } \\
\text { crush and flex/abrasion } \\
\text { resistance }\end{array}$ & $\begin{array}{l}\text { Long-term durability (by } \\
\text { extrapolation) }\end{array}$ & End of all tests \\
\hline $\begin{array}{l}\text { Pulse pressure, duration } \\
\text { Pulse air use }\end{array}$ & $\begin{array}{l}\text { Pulse cleaning parameters } \\
\text { Pulse gas and power } \\
\text { consumption }\end{array}$ & Continuous \\
\hline
\end{tabular}




$$
\begin{aligned}
& \text { DATE } \\
& \text { FILMED } \\
& 8126192
\end{aligned}
$$




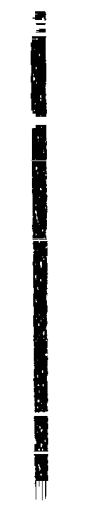

